\title{
Evaluation of energy parameters of fracture during drop weight tear tests based on the analysis of the geometry of the specimens
}

\author{
D. E. Kaputkin ${ }^{\dagger, 1}$, L. M. Kaputkina ${ }^{2}$, A. I. Abakumov ${ }^{3}$, T. S. Esiev ${ }^{4}$ \\ †kaputkin@mail.ru
${ }^{1}$ Moscow State Technical University of Civil Aviation, 20 Kronshtadtskiy blvd., Moscow, 125493, Russia
${ }^{2}$ National University of Science and Technology "MISiS", 4 Leninskiy Av., Moscow, 119049, Russia
${ }^{3}$ Russian Federal Nuclear Center - All-Russian Research Institute of Experimental Physics,
37 Mira Av., Sarov, Nizhny Novgorod region, 607188, Russia
${ }^{4}$ Gazprom VNIIGAZ, 5537, 15, 1 Proektiruemyj proezd, Razvilka, Moscow region, 142717, Russia

\begin{abstract}
An instrumented drop weight tear test allows one to obtain the work of fracture of the specimen. This work monotonously but nonlinearly increases with increasing the test temperature, that is, with increasing toughness of the specimen material. However, part of the work is spent on processes that are not directly related to the properties of the material (friction, etc.). In this work, the total energy expenditures for the deformation of specimens of pipe steel of strength class X80 were determined basing on experimentally measured geometry of the 3D images of specimens and tensile curves of the studied steel, adjusted for the strain rate. In the upper half of the specimen, where tensile deformation was preceded by compression, the total plastic deformation was calculated as the sum of compression and tension. The energy of elastic deformation in all cases was $1 \div 5 \%$ of the total energy of deformation $\left(A_{D}\right)$. An increase in the test temperature results to monotonous but nonlinear increases of $A_{D}$ from $7.5 \mathrm{~kJ}$ at $-67^{\circ} \mathrm{C}$ (brittle fracture) to $15 \mathrm{~kJ}$ at $-40^{\circ} \mathrm{C}$ (mixed fracture) and up to $17 \mathrm{~kJ}$ at $+20^{\circ} \mathrm{C}$ (ductile fracture). Thus, $A_{D}$ is highly sensitive to the transition from brittle to mixed fracture and slowly sensitive to the transition from mixed to ductile fracture. The ratio of $A_{D}$ and the fracture work of the specimen is about $100 \%$ for brittle fracture, $>70 \%$ for mixed fracture, and $<70 \%$ for ductile fracture. Thus, this ratio can be used as an indicator of the fracture type.
\end{abstract}

Keywords: DWTT, pipe steel, work of fracture, deformation.

УДК: 669-9

\section{Оценка энергетических параметров разрушения в ходе испытаний падающим грузом на основе анализа геометрии образов}

\author{
Капуткин Д.Е. ${ }^{\dagger, 1}$ Капуткина Л. М., Абакумов А. И. ${ }^{3}$, Есиев Т. С. ${ }^{4}$ \\ ${ }^{1}$ Московский государственный технический университет гражданской авиации, \\ Кронштадтский 6-p, 20, Москва, 125493, Россия \\ ${ }^{2}$ Национальный исследовательский технологический университет «МИСиС», \\ Ленинский пр., 4, Москва, 119049, Россия \\ ${ }^{3}$ Российский федеральный ядерный центр - Всероссийский научно-исследовательский институт \\ экспериментальной физики, пр. Мира, 37, Саров, Нижегородская обл., 607188, Россия \\ ${ }^{4}$ Газпром ВНИИГАЗ, Проектируемый проезд № 5537, владение 15, строение 1, \\ Развилка, Московская обл., 142717, Россия
}

\footnotetext{
Инструментированные испытания падающим грузом позволяют определить работу разрушения образца. Эта работа монотонно, но нелинейно увеличивается с повышением температуры испытаний, то есть с ростом ударной вязкости материала образца. Однако, часть указанной работы затрачивается на процессы, напрямую не связанные со свойствами материала (например, трение и т. п.). В настоящей статье суммарные затраты энергии на деформацию образцов трубной стали категории прочности X80 были определены из экспериментально измеренной геометрии
} 
3D образов образцов и кривых растяжения исследованной стали с поправками на скорость растяжения. В верхней половине образца, где деформации растяжения предшествует сжатие общая пластическая деформация была рассчитана как сумма сжатия и растяжения. Энергия упругой деформации во всех случаях составляла $1 \div 5 \%$ от общей энергии деформации $\left(A_{D}\right)$. Повышение температуры испытаний приводит к монотонному, но нелинейному увеличению $A_{D}$ от 7.5 кДж при $-67^{\circ} \mathrm{C}$ (хрупкое разрушение) к 15 кДж при $-40^{\circ} \mathrm{C}$ (смешанное разрушение) и вплоть до 17 кДж при $+20^{\circ} \mathrm{C}$ (вязкое разрушение). Следовательно, $A_{D}$ сильно чувствительна к переходу от хрупкого к смешанному разрушению и слабо чувствительна к переходу от смешанного к вязкому разрушению. Отношение $A_{D}$ к работе разрушения образца равно около $100 \%$ для хрупкого разрушения, $>70 \%$ для смешанного разрушения и $<70 \%$ для вязкого разрушения. Таким образом, это отношение может использоваться как показатель типа разрушения.

Ключевые слова: ИПГ, трубная сталь, работа разрушения, работа деформации.

\section{Introduction}

The following standards: GOST 30456-97 [1] (GOvernment STandard, Russia and other CIS countries), ASTM E439 [2] (American Society for Testing and Materials, USA), API 5L3-96 (2003) [3] (American Petroleum Institute, USA) and BS EN 10274: 1999 [4] (British Standard and EuroNorm, $\mathrm{UK}$ and EU) are applied to drop-weight tear tests (DWTT). According to all these standards the ratio of ductile and brittle parts of a fracture is the only measurable parameter. Unfortunately, this parameter has several disadvantages. Firstly, such evaluation is "ambiguous and subjective, because it does not take into account, to the necessary extent, the features and diversity of the structure of fractures" [5]. Secondly, "the complex nature of the formation of the specimen fracture type does not allow it to be interpreted as a criterion for the material toughness and confirms the doubt about the legality of using the fracture type as a quantitative criterion for assessing the crack resistance of welded pipes and other structures" [6]. Even the authors of this type of test, who initially discovered a correlation between fractures after testing of pipes and plate specimens [7], were not able to establish a clear correlation between the parts of fibrous fracture in the destroyed pipes and in the specimens, when they have tested another series of pipes [8]. Thirdly, it is not rational that such technically difficult test gives so little information about the processes that occur in the material during deformation and fracture.

Many methods of mechanical testing (for example $[9,10,11,12])$, supplementing the standard ones, have been developed to increase the accuracy and information content. To increase the amount of objective information about the material fracture process during DWTT, so-called instrumented tests are carried out [13]. The dependence of the acceleration of the striker on time and subsequent integration to obtain the dependence of the force on the coordinate of the striker, allows to obtain energy parameters of fracture also. Two characteristics are automatically obtained from the load - the displacement of the striker diagram in automatic mode. The first of them is called the specimen fracture work $(A) . A$ is equal to the decrease in the kinetic energy of the dropped weight during the contact of the striker with the specimen, and is calculated as the integral of the force on the coordinate. The second characteristic (the so-called crack propagation work $\left(A_{2}\right)$ ) is calculated as the energy spent after reaching the maximum on the smoothed curve of the dependence of force on the coordinate of the striker. Both of these works monotonically, but non-linearly increase with increasing testing temperature and, thus, the material impact strength. Due to the ambiguous meaning of the $A_{2}$ value [14], the following analysis concerns mainly the specimen fracture work $A$.

This work is spent on:

1. elastic deformation of the striker and supports;

2. elastic deformation of the specimen;

3. plastic deformation of the specimen;

4. formation of the fracture surfaces;

5. friction between the specimen and the striker/supports;

6. friction of the movable and fixed parts of the equipment;

7. other losses.

It should be noted, that the losses on subsection "7. other losses" (for example, the formation of elastic (acoustic) waves, overcoming air resistance, etc.) are clearly small. The losses on subsections "1. elastic deformation of the striker and supports" and " 6 . friction of the movable and fixed parts of the equipment" should be minimized by selecting a sufficiently rigid material for the mentioned parts and the correct setting up of the test equipment. It is important that the energy losses mentioned in this subsection, as well as in subsection " 5 . friction between the specimen and the striker/supports" are not directly related to the processes of deformation and fracture of the specimen during testing. The energy for subsection " 4 . the formation of fracture surfaces of the specimen" can be formally calculated by measuring the surface area of the fracture and multiplying it by surface tension, but it is difficult to determine experimentally. However, it is known that, for metals with high toughness, the energy of formation of new surfaces is small compared to the energy of deformation.

Energy losses for subsections " 2 . elastic deformation of the specimen" and "3. plastic deformation of the specimen" can be calculated based on experimentally measured specimen geometry and tensile curves of the tested material at different temperatures. Similar measurements carried out in tests of other types, in particular with quasistatic tension, have long proved the applicability and information content of such geometric measurements [15].

Thus, the purpose of this work is to develop a technique for evaluation energy losses on deformation and fracture of the specimen during DWTT basing on the analysis of the 3D-image of fractured specimen. 


\section{Experimentals}

Standard (GOST 30456-97) DWTT specimens of $27.7 \mathrm{~mm}$ thick were produced from a single-longitudinal-seam pipe for gas pipelines with a diameter of $1420 \mathrm{~mm}$ manufactured from steel of strength class X80. The specimens were cut so that a V-shaped notch of a standard depth of $5 \mathrm{~mm}$ was oriented along the pipe. They were tested on DWT 40-5 drop-hammer impact testing equipment with a weight of 2.5 tons using a three-point shock-bending scheme at temperatures from -67 to $+20^{\circ} \mathrm{C}$ in steps of $\sim 10^{\circ} \mathrm{C}$ (Fig. 1). We have tested two specimens for each temperature. The total energy losses $A$ and work of the crack propagation $A_{2}$ were calculated using the software embedded into the testing equipment, depending on the acceleration of the dropped weight vs time. An accuracy of measurements was $\pm 5^{\circ} \mathrm{C}$ for the temperature and $\pm(5 \div 7) \%$ for energetic parameters.

Quasi-static tensile tests were carried out on standard cylindrical specimens with an operating zone of $4 \mathrm{~mm}$ in diameter and $20 \mathrm{~mm}$ in length (GOST 1497-84 [16]) on an Instron-3369 universal testing machine at temperatures of $+20,-20$ and $-40^{\circ} \mathrm{C}$ and tensile rates of 10 and $50 \mathrm{~mm} / \mathrm{min}$.

The fractured specimen geometry was measured using an ATOS II XL non-contact optical digitizing system (Advanced

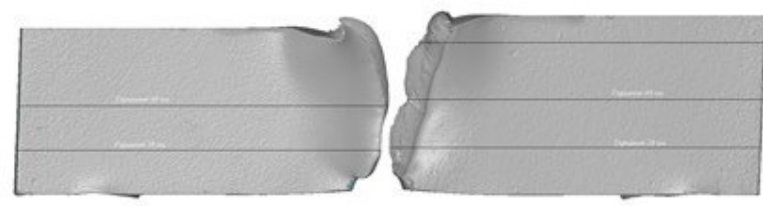

a

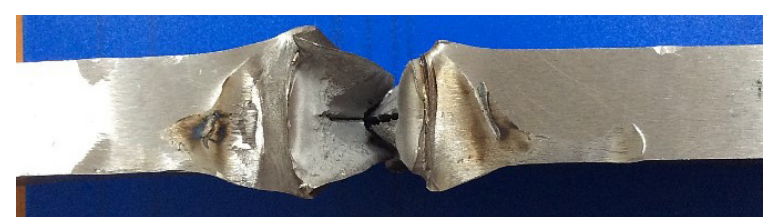

b

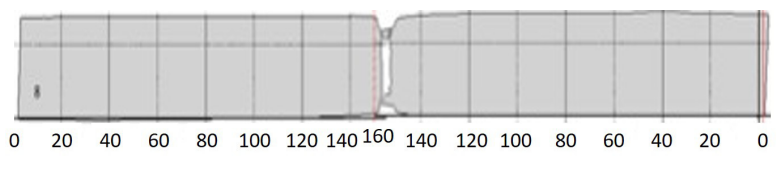

c

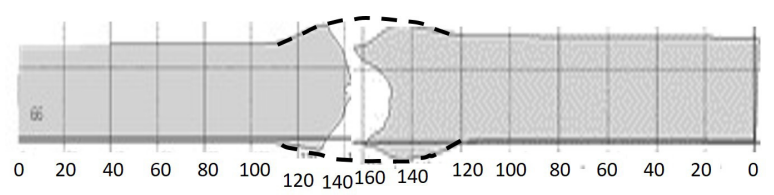

d

Fig. 1. (Color online) Specimen after DWTT at $+20^{\circ} \mathrm{C}$; side view, 3D-image (a); view from above, photo (b); schemes of sections of the specimen 3D-image at 8 (c) and $66 \mathrm{~mm}$ (d) from the specimen bottom. Dashed line demonstrates maximal compression deformation.
Topometric Sensor). The digitalizing step was $5 \mathrm{~mm}$ in hight and $0.1 \mathrm{~mm}$ in other directions. Solidworks and Geomagic Quality software were used to recognize and decrypt the shape of the specimen.

\section{Discussion}

The dropped weight energy spent for the elastic and plastic deformation of the specimen. Measuring of the shape changes allows us to determine the plastic deformation value. The specific work of the plastic deformation for the volume unit $a_{p}$ is calculated as

$$
a_{p}=\int \sigma \cdot d \varepsilon_{p}
$$

where $\sigma$ means tensile stress, $\varepsilon_{p}$ means relative plastic deformation. Thus, it is necessary to use the dependence of tensile stresses vs plastic deformation (Fig. 2b). This dependence was calculated by subtracting the elastic deformation (Young's modulus of elasticity was taken as $200 \mathrm{GPa}$ ) from the experimental $\sigma / \varepsilon$ curve (Fig. $2 \mathrm{a}$ ).

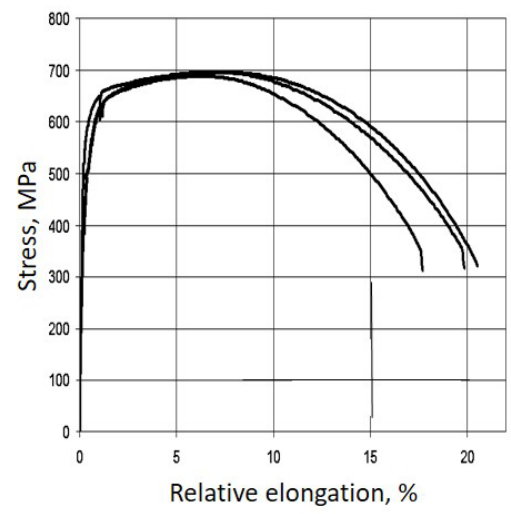

a

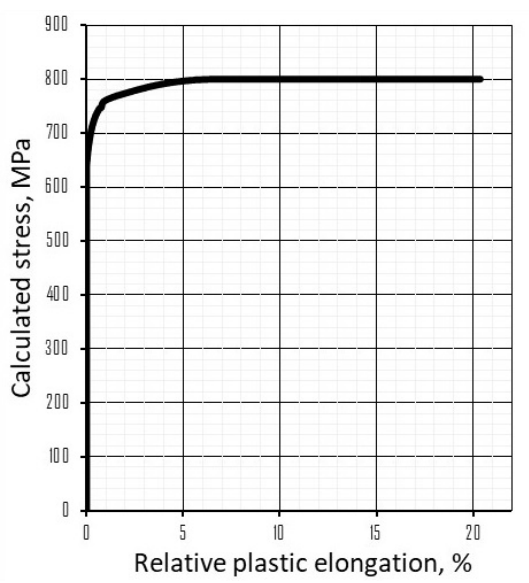

$\mathrm{b}$

Fig. 2. Tensile stress vs strain dependences of three various specimens at temperature $+20^{\circ} \mathrm{C}$ (a) and calculated corresponding tensile stress vs plastic elongation dependence (b).

Table 1. The results of tensile tests of steel of strength class X80 at different loading speeds and test temperatures.

\begin{tabular}{|c|c|c|c|c|}
\hline Test temperature, ${ }^{\circ} \mathrm{C}$ & Deformation rate, $\mathrm{mm} / \mathrm{min}$ & Relative elongation, $\%$ & Ultimate tensile strength, MPa & Yield strength, MPa \\
\hline-40 & 10 & $21.7 \pm 1.0$ & $764 \pm 9$ & \\
\hline-20 & 10 & $21.7 \pm 1.0$ & $746 \pm 5$ & \\
\hline+20 & 10 & $22.5 \pm 2.5$ & $676 \pm 7$ & $505 \pm 11$ \\
\hline+20 & 50 & $22.0 \pm 2.0$ & $699 \pm 6$ & $542 \pm 7$ \\
\hline
\end{tabular}


To estimate the relative plastic strain $\varepsilon_{p}$, we used the results of measuring the thickness of a given section of the 3D-image of the specimen. The change in thickness of the specimen during DWTT is much less than the length of the crack (the specimen total height without the notch depth). Therefore, we can assume that (basing on the law of constancy of volume for a plastically deformed material), the relative change in the thickness of the cross section is equal to the relative elongation $\varepsilon_{p}$, which was used to calculate the energy of plastic deformation.

The energy volume density of elastic deformation $a_{e^{\prime}}$ which preceded the measured plastic, was determined using Hooke's law:

$$
a_{e}=\frac{\sigma \cdot \varepsilon_{e}}{2}=\frac{\sigma^{2}}{2 \cdot E},
$$

where $\sigma$ means the stress corresponding to the measured plastic strain, $\varepsilon_{e}$ means the calculated value of the elastic strain preceded the measured plastic strain. The calculated values of the energy of elastic, plastic, and total deformation were determined by integration over the volume.

Tensile diagrams for the studied steel of strength class X80 are shown in Fig. 3.

The average curve was chosen as the tensile curve involved in further calculations (an example is shown in Fig. 2 a). At the same time, it was verified that the use of any tension curves for calculations changes the result by no more than $0.3 \%$.

The dependences of the tensile stress vs plastic deformation were calculated by deduction of the elastic strain from the total strain. Since the reduction of the conditional stress after reaching the ultimate tensile strength (UTS) is caused not by softening the specimen, but by a decrease in the effective cross-sectional area, the stresses during deformations after reaching the UTS were taken equal to the UTS (see Fig. $2 \mathrm{~b}$ ). Since, with an increase in the strain rate, the stress-strain curve increases (Table 1), the stress levels obtained at a tensile speed of $10 \mathrm{~mm} / \mathrm{min}$ in accordance with [17] were increased by $15 \%$.

The shape of the halves of each DWTT specimen (see Fig. 1) was digitized in 3D. Next, the thickness of the section was determined layer-by-layer (at the same distance

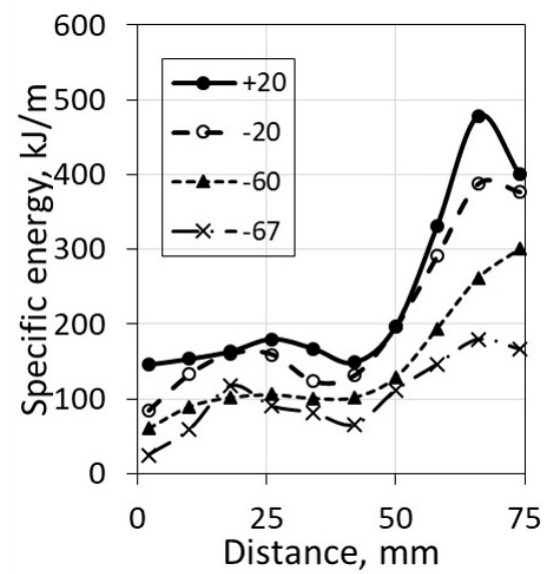

Fig. 3. Dependences of the deformation energy density per unit of height of the specimen $(\mathrm{MJ} / \mathrm{m})$ vs the distance to the layer from the bottom surface of the specimen at different temperatures $\left({ }^{\circ} \mathrm{C}\right)$. from the lower surface of the specimen), and the residual plastic deformation and elastic deformation preceding the obtained plastic were determined. In the upper zones of the specimen, where plastic tensile deformation was preceded by compression (see Fig. 1b,d), the total plastic deformation $\varepsilon_{p}$ was calculated as the sum of compression and tensile deformations. Since both the physical mechanisms and the parameters of the deformation diagrams for tension and compression are the similar [18], we have used the tensile diagrams (Fig. 2) for energy calculations for both cases. The volume density of the deformation energy was calculated as the sum of the elastic and plastic parts. The elastic deformation in all cases was from 1 to $5 \%$ of the total energy of deformation.

The curves of the dependence of the energy density spent on the deformation of each horizontal layer on the distance to this layer from the lower surface of the specimen are shown in Fig. 3. This pattern shows that the energy density, spent on the deformation of each layer have a tendency to increase with increasing test temperature. Note that the calculations for the uppermost layer are very inaccurate, because it was deformed according to a complex scheme and the degree of deformation is difficult to estimate.

The calculated total energy spent on the specimen deformation $\left(A_{D}\right)$ :

$$
A_{D}=\int_{V}\left(a_{p}+a_{e}\right) \cdot d V
$$

where $V$ means the total volume of the specimen, monotonously increasing with an increase in the temperature of the tests (Fig. 4). During the transition from brittle fracture at $-67^{\circ} \mathrm{C}$ to mixed brittle-ductile one at $-40^{\circ} \mathrm{C} A_{D}$ increases significantly (doubles), but a further increase at temperatures up to $+20^{\circ} \mathrm{C}$ and, accordingly, a transition to ductile fracture results in a slight (not more than $10 \div 15 \%$ ) increase in $A_{D}$.

A comparison of the $A_{D}$ and the work of fracture of the specimen $(A)$, determined from braking of the dropped weight during the DWTT (Fig. 5), shows that for brittle fracture $A_{D}$ is almost equal to $A$, for mixed fracture $A_{D}$ is more than $70 \%$ of $A$, and ductile fracture $A_{D}$ is less than $70 \%$ of $A$. Thus the ratio $A_{D} / A$ is an indicator of the fracture type.

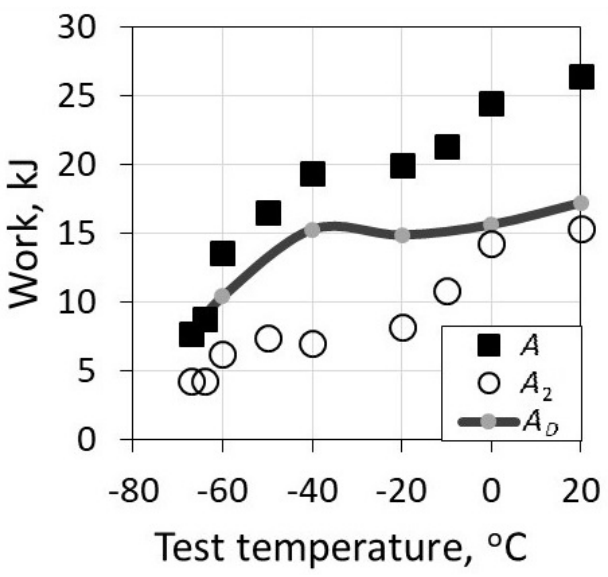

Fig. 4. Dependence of the specimen fracture work $(A)$, the crack propagation work $\left(A_{2}\right)$ and the energy spent on specimen deformation $\left(A_{D}\right)$ vs DWTT temperature. 


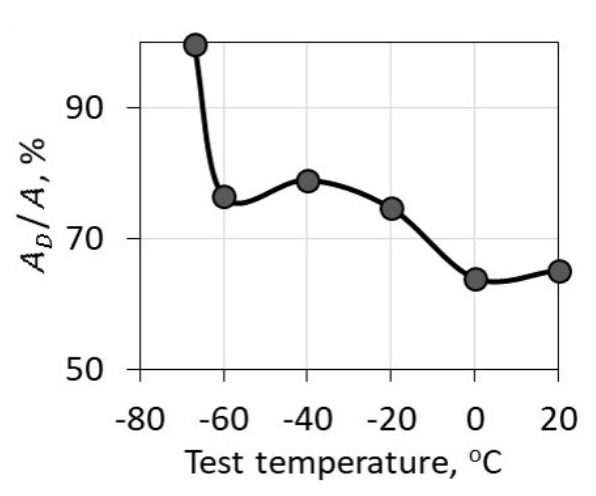

Fig. 5. Dependence of the ratio of the energy spent on specimen deformation $\left(A_{D}\right)$ to the specimen fracture work $(A)$ vs DWTT temperature.

\section{Conclusions}

1. A technique for evaluation of energy losses for elastic and plastic deformation during DWTT without using special equipment for instrumented tests is developed. This technique is based on the analysis of both $3 \mathrm{D}$ images of fractured DWTT specimens and parameters of quasi-static tensile diagrams of the same steel.

2. Energy losses for elastic and plastic deformation during DWTT, estimated by the developed technique, monotonously nonlinearly increase with increasing the test temperature of pipe steel of strength class $\mathrm{X} 80$ from lower $-60^{\circ} \mathrm{C}$ to $+20^{\circ} \mathrm{C}$.

3. The mentioned energy losses are $>90 \%$ of the total fracture work for brittle fracture, $70 \div 90 \%$ for mixed fracture, and $<70 \%$ for ductile fracture.

Acknowledgement. Authors are thankful to Dr. Glebov A. G. for his help in experiments.

\section{References}

1. GOST 30456-97. Metal products. Sheet metal and steel pipes. Impact bending test methods (1997). (in Russian) [ГОСТ 30456-97. Металлопродукция. Прокат листовой и трубы стальные. Методы испытания на ударный изгиб (1997).]

2. ASTM E436. Standard test method for Drop-Weight Tear Tests of Ferritic Steels (2014).

3. API 5L3-96 (2003). Recommended Practice for Conducting Drop-Weight Tear Tests on Line Pipe. Second Edition (2003).
4. BS EN 10274:1999. Metallic Materials Drop Weight Tear Tests (1999).

5. V.S. Vakhrusheva, E.A. Grimalovskaya. Metaloznavstvo ta Termichna obrobka metaliv. 3, 11 (2015). (in Russian) [В.С. Вахрушева, Е.А. Грималовская. Металознавство та термічна обробка металів. 3, 11 (2015).]

6. Yu.I. Pashkov, Yu. V. Bezgans. Vestnik YuUrGU. Ser. "Metallurgya". 15 (1), 113 (2015). (in Russian) [Ю.И. Пашков, Ю.В. Безганс. Вестник ЮУргУ. Сер. «Металлургия». 15 (1), 113 (2015).]

7. G. M. McClure, A. R. Duffy, R. J. Eiber. Trans. ASME. B. 87 (3), 265 (1965). Crossref

8. R.J. Eiber, A.R. Duffy, G.M. McClure. Significance of the Drop-Weight Tear Test and Charpy V-Notch Impact Test Results. In: Impact Testing of Metals. ASTM Special Technical Publication, Philadelphia, ASTM (1970) pp. 181-191. Crossref

9. Certificate of authorship SU 714223 A1, 05.02.1980. (in Russian) [Авт. свид. СССР SU 714223 А1, 05.02.1980.]

10. I. V. Ushakov, V.A. Feodorov, I.J. Permyakova. Proc. SPIE. The international Society for Optical Engineering. 5127, 246 (2002). Crossref

11. I. V. Ushakov. Proc. SPIE - The International Society for Optical Engineering. 6597, 659714 (2007). Crossref

12. Certificate of authorship SU 767616 A1, 30.09.1980. (in Russian) [Авт. свид. СССР SU 767616 A1, 30.09.1980.]

13. N. Osborne. M. Bergsten. Advanced Materials and Processes. 167 (2), 26 (2009).

14. M.A. Stremel', A.B. Arabei, A.G. Glebov, I. Yu. Pyshmintsev, T.S. Esiev, A.I. Abakumov. Russian Metallurgy (Metally). 4, 411 (2018). Crossref

15. M.A. Shtremel. Laboratory practicum on course of "Metal Physics". P. 1. Moscow, MISiS (1969) 81 p. (in Russian) [M.A. Штремель. Лабораторный практикум по спецкурсу «Прочность сплавов». Ч.1. Москва, МИСиС (1969) 81 с.]

16. GOST 1497-84. Metals. Methods for tensile tests (1984). (in Russian) [ГОСТ 1497-84. Металлы. Методы испытаний на растяжение (1984).]

17. M. A. Shtremel. Fracture. V. 1. Moscow, MISiS publ. (2015) 670 p. (in Russian) [M. А. Штремель. Разрушение. Том 1. Москва, МИСиС (2015) 670 c.]

18. M.L. Bernshtein, V.A. Zaymovskiy. Mechanical properties of metals. Moscow, Metallurgiya (1979) 495 p. (in Russian) [М.Л. Бернштейн, В.А. Займовский. Механические свойства металлов. Москва, Металлургия (1979) 495 с.] 